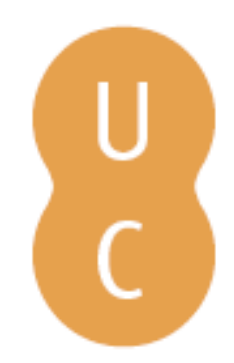

\title{
nombalina
}

\section{Espaço e paisagem em Doze Naus de Manuel Alegre}

\author{
Autor(es): $\quad$ Ferreira, José Ribeiro
}

Publicado por: Associação Portuguesa de Estudos Clássicos; Imprensa da

URL

persistente: URI:http://hdl.handle.net/10316.2/31844

DOI: $\quad$ DOI:http://dx.doi.org/10.14195/978-972-98142-2-8_22

Accessed : $\quad$ 26-Apr-2023 12:21:39

A navegação consulta e descarregamento dos títulos inseridos nas Bibliotecas Digitais UC Digitalis, UC Pombalina e UC Impactum, pressupõem a aceitação plena e sem reservas dos Termos e Condições de Uso destas Bibliotecas Digitais, disponíveis em https://digitalis.uc.pt/pt-pt/termos.

Conforme exposto nos referidos Termos e Condições de Uso, o descarregamento de títulos de acesso restrito requer uma licença válida de autorização devendo o utilizador aceder ao(s) documento(s) a partir de um endereço de IP da instituição detentora da supramencionada licença.

Ao utilizador é apenas permitido o descarregamento para uso pessoal, pelo que o emprego do(s) título(s) descarregado(s) para outro fim, designadamente comercial, carece de autorização do respetivo autor ou editor da obra.

Na medida em que todas as obras da UC Digitalis se encontram protegidas pelo Código do Direito de Autor e Direitos Conexos e demais legislação aplicável, toda a cópia, parcial ou total, deste documento, nos casos em que é legalmente admitida, deverá conter ou fazer-se acompanhar por este aviso.

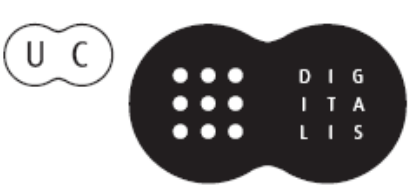




\section{Espaços e Paisagens}

\section{Antiguidade Clássica e Heranças Contemporâneas}

Vol. Il Línguas e Literaturas. Idade Média. Renascimento. Recepção

Francisco de Oliveira, Cláudia Teixeira, Paula Barata Dias (Coords.)

IMPRENSA DA UNIVERSIDADE DE COIMBRA 


\title{
ESPAÇO E PAISAGEM EM DOZE NAUS \\ DE MANUEL ALEGRE
}

\author{
José Ribeiro Ferreira \\ Universidade de Coimbra \\ Centro de Estudos Clássicos e Humanisticos
}

\begin{abstract}
Resumo
O trabalho procura analisar o espaço e a paisagem no último livro de poemas de Manuel Alegre, Doze Naus, em especial os espaços e paisagens greco-romanos. São muitas as composições que têm um espaço ou paisagem subjacente. Sobretudo nota-se grande insatisfação e uma busca constante de um lugar, da Ítaca ideal que nunca é o sítio em que se está ou chega. Relembro, a título de exemplo, o poema "Mar absoluto" em que as naus de Ulisses partem, «navios a sair do cais / para outro espaço outro crepúsculo outra aurora». E todas falham, com excepção de uma que chega ao seu destino, entra pela poesia dentro e o poeta é esse navegar, é «o que procura mesmo se ninguém responde», é «o que pergunta pelo mar». Outro exemplo elucidativo é o poema "A curva", que é o ponto ou sítio onde «alguém tem de aparecer», porque a «vida toda» é «sonho a esperar sempre / naquela curva não importa quem».
\end{abstract}

A cultura clássica é rio que corre há mais de dois mil anos sem cessar, nunca o mesmo e nunca igual. Aluviões constantes, transmitidos ao longo dos tempos, adubam os produtos e criações da mente humana, sempre novos, sempre outros. E o baú da memória da humanidade recolhe os estratos sucessivos que aí ficam depositados e aí permanecem pujantes e vivos, sempre prontos a ser desfiados à mínima alusão ou associação.

O livro de poemas Doze Naus de Manuel Alegre é mais uma expressão desse rio que não pára de fluir. E nele as paisagens de Tróia, de Ítaca, de Lisboa, do Tejo, de Portugal aparecem como espaço ou teatro da vida de Ulisses, do poeta, do povo português. E todos eles se intercruzam, se identificam, como paisagens, espaços e símbolos de Portugal e do temperamento português.

Em Doze Naus o mito de Ulisses permanece essencial. E, ao longo do livro, o poeta continua a sua busca insatisfeita. São inclusive tópicos insistentes em especial nos poemas iniciais e nos finais - o mar, o barco, o rio, o vento. $\mathrm{O}$ próprio título do livro tem subjacente o número de barcos comandados pelo herói homérico na expedição contra Tróia, como vem referido no Canto 2 da 
Ilíada, no célebre episódio do "Catálogo das naus" (vv. 631-637). Traduzo os versos em causa:

Por sua vez Ulisses comandava os magnânimos Cefalénios,
que habitavam Itaca e o Nériton de folhas agitadas pelo vento,
e administravam Crocileia e a áspera Egílipe;
os que detinham Zacinto e habitavam Samos,
os que possuiam o continente e habitavam a orla maritima.
Era seu comandante Ulisses, igual de Zeus no na prudência.
E com ele seguiam doze naus de cascos vermelhos.

De Tróia essas mesmas doze naus partiram com o herói de regresso a Ítaca (Odisseia 9. 159), embora a maioria delas sofresse a destruição (Odisseia 10127-132).

E esse número doze de naus aparecerá em vários poemas desta colectânea de Manuel Alegre. Em "Mar absoluto" (p. 19) - poema que parece repercutir "Mar português" de Fernando Pessoa e que abordarei adiante com mais pormenor - o sujeito vê «as doze naus de Ulisses ou talvez / a vida toda nesse breve instante / em que disseste mar pela primeira vez», as «doze proas pintadas de vermelho» (p. 20). O número de naus e a sua cor voltam a ser especificados no poema seguinte, intitulado precisamente "Doze naus pintadas de vermelho" (p. 22). Nele o poeta - identificado com Ulisses e com o povo português, como é usual no autor de Senhora das Tempestades - confia embarcar «nas doze naus pintadas de vermelho» que estão fundeadas, "paradas em frente da cidade de Príamo». Agora, porém, Ulisses está ferido e sentado, a pensar nas palavras que dirigiu ao guerreiro inimigo Soco, «sobre a morte e o obscuro destino», enquanto espera que chegue o médico

que lhe corre da coxa para o meio da página
junto das doze naus pintadas de vermelho.

O poema tem subjacente o passo do Canto 11 da Ilíada (vv. 426-488) em que Ulisses é atingido por Soco para vingar a morte do irmão Cárops, rasgando-lhe o flanco com a lança (v. 437) de onde o sangue jorra (v. 458). O Cefalénio, apesar de ferido, mata então Soco e dirige-lhe palavras duras, onde aparece referência expressa à morte e ao negro destino (v. 443: phonon kai kêran mélainan) que o espera, tópico também presente no poema de Manuel Alegre. Cito os versos em tradução de Frederico Lourenço (vv. 441-455):

\footnotetext{
"Desgraçado!' Agora veio ao teu encontro a morte escarpada!

Decerto me impediste de guerrear contra os Troianos;

mas a ti declaro eu que a morte e o escuro destino

te virão neste dia: pela minha lança subjugado,
} 
trar-me-ás a glória; ao Hades de nobres poldros, a tua alma."

Falou; e o outro recuou e lançou-se na fuga.

Enquanto se voltava, nas costas entre os ombros lhe fixou

Ulisses a lança, que lhe trespassou o peito.

Tombou com um estrondo e sobre ele exultou o divino Ulisses:

"Ó Soco, filho do fogoso Hipaso, domador de cavalos!

Rápido te sobreveio o termo da morte; não lhe escapaste.

Desgraçado! Teu pai e tua excelsa mãe não te fecharão

os olhos na morte, mas as aves de rapina que devoram

carne crua te dilacerarão, batendo todas cerradas as asas

à tua volta. Por mim, se morrer, sepultar-me-ão os Argivos."

Mas a intertextualidade do Canto 11 da Ilíada no poema "Doze naus pintadas de vermelho" é mais densa do que a simples referência a Soco e ao ferimento de Ulisses. Nesse teatro de guerra sem quartel que o Canto 11 do poema homérico descreve, os ferimentos dos combatentes aqueus são constantes (Agamémnon, Diomedes, Ulisses, Eurípilo). Quem os consola e os socorre com o apoio do médico Macáon é Nestor, o ancião Nestor de Gerénia. $\mathrm{E}$ a esse pormenor alude o poema de Manuel Alegre, ao especificar que Ulisses pensa nas palavras ditas a Soco,

à espera que Nestor de Gerénia o Velho

traga o médico (talvez Mácoon) para estancar o sangue

Vejamos o poema na íntegra, que é dedicado a Teresa Rita Lopes:

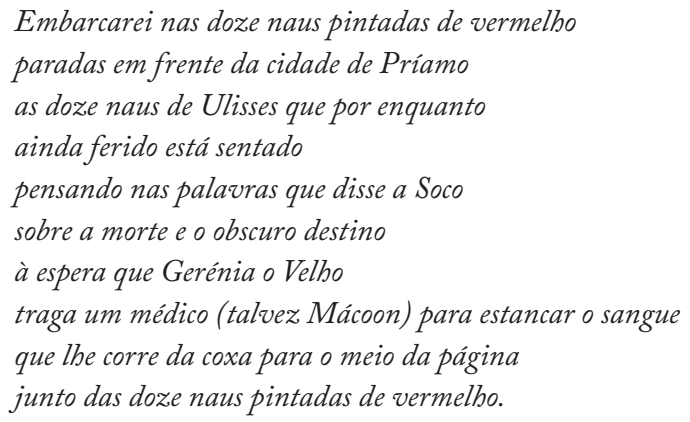

O final do poema dá um contexto e estabelece um espaço de ficção. $\mathrm{O}$ sangue que mana da coxa de Ulisses corre afinal para o meio da página, colocado portanto no domínio da criação poética.

Em 2001, publiquei pequeno opúsculo sobre os temas clássicos na poesia desse poeta, a que dei o título de Manuel Alegre: Ulisses ou os caminhos de eterna busca, em que mostrava ser o mito do filho de Laertes central, talvez mesmo o mais importante na obra do autor de O Canto e as Armas: Ulisses - que castiga 
a insolência e injustiça e apresenta como ideias centrais o exilio e a errância, quer físicos, quer interiores - aparece de modo geral equiparado ao sujeito poético e ao povo português. Sujeito poético, povo português, figura mítica deixaram o seu espaço natural e as paisagens natais para longo tempo andarem errantes por diversas terras e povos e por fim regressarem à sua terra, a Ítaca que em Manuel Alegre, com muita frequência, aparece como a terra pátria e também como algo de ideal (a ilha que fica sempre mais a sul, a tão azul, como diz em Um Barco para Ítaca) que a insatisfação humana sempre busca sem jamais a encontrar, porque a Ítaca que se procura nunca é a aquela a que se chega.

$\mathrm{E}$, como Ulisses se identifica com o povo português, o sangue que corre da ferida simboliza o sangue e o sofrimento de Portugal. Um sofrimento equacionado em vários momentos da nossa história que marcaram o ser português. Um sofrimento que o fio da memória vai desdobando ao longo de Doze Naus. É sobre esse espaço Ítaca-Portugal que Ulisses-poeta pensa, desejando - é evidente - que nele reflectisse também o povo português. Essa é a preocupação do livro do princípio ao fim.

E, como ilustração dessa inquirição e insatisfação, permita-se-me apenas, a concluir, a citação e breve alusão ao poema "A curva" (p. 87), o último do livro, que é outro exemplo elucidativo de busca constante, de questionação permanente e nunca satisfeita. A curva é espaço abstracto e simbólico que nos separa do desconhecido, do incerto; a curva é o ponto ou sítio onde «alguém tem de aparecer», porque a «vida toda» é «sonho a esperar sempre / naquela curva não importa quem», mas alguém que «há-de aparecer» e que aponte um aquém ou um além, ou mesmo simplesmente e só «o horizonte / daquela curva onde se espera alguém». O poema é constituído por três quadras em rima cruzada $(A B A B)$, onde se insiste no indefinido "alguém", a cada passo em anáfora (início das estrofes $1 \mathrm{e}$ 3 , bem como a começar o verso 3 da estrofe 2), e onde as aliterações surgem em vários versos (s nos versos 4,5 , c ou q no 6 e a no 9). Transcrevo o poema:

Alguém tem de aparecer naquela curva mesmo que se não saiba o que é depois se estrada larga ou morte ou água turva se solidão ou um a ser já dois.

$A$ vida toda em sonho a esperar sempre naquela curva não importa quem alguém que diga o quê e saia ou entre ainda que depois não mais ninguém.

Alguém há-de aparecer alguém que aponte quem sabe se um aquém ou se um além ou nada mais senão o horizonte daquela curva onde se espera alguém. 